\title{
Effect of an Enzyme Blend on the Performance, Diet Metabolizability, Phosphorous Retention, and Bone Mineralization of Broilers Fed Diets Containing Defatted Rice Bran
}

\section{-Author(s)}

Moraes ML Ledur V'

Kessler AM

Machado PHM

Della MPI

Ribeiro $A M L^{\prime}$

Universidade Federal do Rio Grande do Sul, Departamento de Zootecnia.

\section{-Mail Address}

Corresponding author e-mail address Mariana Lemos de Moraes

Av. Bento Gonçalves 7712, Porto Alegre RS, 91540-000, Brazil

E-mail: moraesmlm@gmail.com

\section{-Keywords}

Broiler chicken, defatted rice bran, enzyme blend, metabolism, mineral retention, performance.

\section{ABSTRACT}

An experiment was conducted to evaluate the effect of an enzyme blend (EB) on the performance, diet metabolizability, phosphorus (P) retention, and bone mineralization of broilers fed diets containing $10 \%$ defatted rice bran (DRB). In total, 432 one- to 38-d-old male Cobb broilers were evaluated according to a completely randomized experimental design in $3 \times 2$ factorial arrangement. Three diets were tested with two nutrient reductions (NR) in the matrix (standard diet; NR I of $75 \mathrm{kcal} / \mathrm{kg} \mathrm{ME}, 0.1 \%$ Ca and $0.1 \%$ available P; and NR II of $100 \mathrm{kcal} / \mathrm{kg} \mathrm{ME}, 0.1 \% \mathrm{Ca}$ and $0.1 \%$ available P) with or without the addition of an EB $(200 \mathrm{~g} / \mathrm{t})$. The coefficients of total tract apparent retention (CTTAR) of the diets and $\mathrm{P}$ retention were determined by collecting excreta during two periods (14 to 17 and 28 to $31 \mathrm{~d}$ ). As expected, birds fed the standard diet had higher BW, BW gain, and G:F compared to birds on the NR diets. The EB did not show any positive effects on CTTAR or on performance; however, birds fed the EB retained $6.58 \%$ more $P$ from d 14 to $17(p \leq 0.07)$ and $8.55 \%$ from $d 28$ to 31 $(p<0.05)$. Tibiotarsus ash percentage also increased by $2.45 \%$ ( $p \leq$ 0.06 ) on d 38. In diets containing 10\% DRB, the enzyme blend showed biological activity improving $\mathrm{P}$ retention and tibiotarsus mineralization.

\section{INTRODUCTION}

Traditionally, corn and soybean meal are the main components of poultry diets. Seeking to reduce feed costs and to comply with public and environmental demands, alternative feeds have been studied to identify their best cost-benefit ratio. In this context, rice byproducts have proven to be an interesting option.

Rice bran (RB) corresponds to $8 \%$ of the volume of the grain and contains adequate amount of nutrients. However, its use is limited by its high oil content, which is approximately 18\% (Van Hoed et al., 2006; Krishna \& Chandrasekaran, 2012). Defatted rice bran (DRB) is the result of the extraction of the oil from the RB, and because it is less susceptible to rancidity, it may be stored for longer periods (Chae et al., 2002). Rice bran can be included in animal diets; however, its anti-nutritional factors may limit its use. These include non-starch polysaccharides (NSP), which in large amounts affect animal performance by increasing the viscosity of the bolus and reducing digestibility. In RB, arabinoxylans comprise the largest fraction of NSP (Conte et al., 2002). Another problem of RB use is its high content of phytic acid, which renders $P$ unavailable in addition of impairing protein and starch digestion (Oliveira et al., 2008). According to Domene et al. (1996), $100 \mathrm{~g}$ of DRB contain approximately 6.25 to $6.9 \mathrm{~g}$ of phytic acid.

One nutritional strategy to increase the availability of nutrients in RB is the addition of exogenous enzymes individually or in groups, which are 
known as enzyme blends (EB). Enzymes aid digestion by hydrolyzing NSP chemical bonds, breaking cell wall fibers, supplying more energy, reducing viscosity, and breaking down proteins and phytic acid (Soto-Salanova et al., 1996).

In this context, this study aimed at evaluating the effect of inclusion of an EB composed of several enzymes (phytase, protease, xylanase, beta-glucanase, cellulase, pectinase, fungal protease, and amylase) in regular or reduced-nutrient diets containing 10\% DRB on the performance, diet metabolizability, P retention, and bone mineralization of broilers.

\section{MATERIAL AND METHODS}

All procedures involving animals were in accordance with Brazilian guidelines and approved by the Ethics Committee of the Federal University of Rio Grande do Sul. The Brazilian guidelines are based on Federal Act No. 11794 of October 8, 2008.

A total number of 432 one-d-old broiler chickens were housed in 36 metabolic cages in an environmentally controlled room. Each cage represented an experimental unit. During the starter phase ( 1 to 21 days d), 12 broilers were housed per cage measuring $0.83 \mathrm{~m}^{2}$, and during the grower phase (21 to $38 \mathrm{~d}$ ), eight broilers were housed per cage measuring $0.77 \mathrm{~m}^{2}$.

Two rearing phases were considered in diet formulation: starter, from d 1 to 21, and grower, from $d 21$ to 38 . The diets were formulated using the nutritional levels recommended by the Tabelas Brasileiras de Aves e Suínos (Rostagno et al., 2005). Defatted rice bran was included at $10 \%$ in the diets of both periods (Table 1).

The study was performed according to a $3 \times 2$ factorial arrangement, consisting of three diets: a control diet and two diets with nutrient reductions $(\mathrm{NR})$, and the inclusion or not of an EB derived from Aspergillus niger added at $200 \mathrm{~g} / \mathrm{t}$ diet (Allzyme SSF () . The EB contained phytase, protease, xylanase, beta-glucanase, cellulase, pectinase, fungal protease, and amylase. Nutrient reductions were based on the manufacturer's information on the capability of the EB to supply dietary nutrients. The control diet consisted of a standard broiler diet. The NR I diet was formulated with less $75 \mathrm{kcal} \mathrm{ME/}$ $\mathrm{kg}, 0.1 \%$ of $\mathrm{Ca}$ and $0.1 \%$ of available P; and the NR II diet was formulated less $100 \mathrm{kcal} \mathrm{ME} / \mathrm{kg}, 0.1 \%$ of $\mathrm{Ca}$ and $0.1 \%$ of available P.
Individual broiler body weight (BW), feed intake $(\mathrm{Fl}), \mathrm{BW}$ gain (BWG), and gain:feed ratio (G:F) were determined for both starter and grower periods and for the total experimental period.

The coefficients of total tract apparent retention (CTTAR) were determined between $d 14$ to 17 and d 28 to 31 using total excreta collection method. The excreta were daily collected, weighed, and homogenized. Aliquots (10\% of the total excreta) were stored at $-16^{\circ} \mathrm{C}$ for subsequent analyses. After thawing, the excreta were added with $\mathrm{HCl}$ solution to avoid $\mathrm{N}$ losses and dried in an oven at $60^{\circ} \mathrm{C}$ for $72 \mathrm{~h}$ and then ground in a one-mm knife mill (Ribeiro et al., 2001). Analyses were performed according to AOAC Official Methods of Analysis (1995) for dry matter (DM, method number 930.15), crude protein (CP, method number 976.05; according to Prates, 2007), ash (method number 942.05), and gross energy (GE, bomb calorimeter, C2000 - IKA Werke GmbH \& Co. $K G$, Staufen, Germany). The CTTAR of DM, CP, GE, and the apparent metabolizable energy (AME) content of the experimental diets were then calculated. The $P$ content of the diets and the excreta were quantified by colorimetry (Tedesco et al., 1995). Phosphorous retention was expressed in grams.

Birds with representative body weight of their cages were selected on $\mathrm{d} 21$ and 38 and euthanized for the determination of bone mineralization of the tibiotarsus. The left tibiotarsus of 18 broilers per treatment (three/ replicate) was collected. Samples were dried in an oven at $105^{\circ} \mathrm{C}$ for $12 \mathrm{~h}$ and placed in a muffle at $550^{\circ} \mathrm{C}$ for $4 \mathrm{~h}$ (Yan et al. 2005). Tibiotarsus ash content was expressed as percentage of DM.

Data were submitted to analysis of variance and means were compared by the LS Means test using the GLM procedure of SAS statistical package (SAS Inst. Inc., Cary, NC) according to a completely randomized design in a factorial arrangement. The pooled standard error of the mean (SEM) was calculated by averaging the SEM by the SAS GLM procedure for each parameter. Performance and CTTAR data were analyzed according to a $3 \times 2$ factorial and the statistical model included the effects of diet (standard, NR I, and NR II), EB (inclusion or not), and their interactions. Phosphorus retention and bone mineralization data were analyzed according to a $2 \times 2$ factorial arrangement including the effects of the dietary nutrient reduction (standard diet vs. NR I + NR II diets), EB (inclusion or not), and their interactions. The effects of the diets NR I and II were analyzed together because they contained equal $\mathrm{P}$ and $\mathrm{Ca}$ levels. 
Table 1 - Composition of experimental diets, as fed basis

\begin{tabular}{|c|c|c|c|c|c|c|}
\hline \multirow[b]{2}{*}{ Item } & \multicolumn{3}{|c|}{ Starter diet (1 to $21 \mathrm{~d}$ ) } & \multicolumn{3}{|c|}{ Grower diet (21 to $38 \mathrm{~d}$ ) } \\
\hline & $\mathrm{ST} / \mathrm{ST}+\mathrm{EB}$ & $\mathrm{NR} \mid / \mathrm{NR}$ I+EB & NR II / NR II+EB & $\mathrm{ST} / \mathrm{ST}+\mathrm{EB}$ & $\mathrm{NR}$ I / NR I+EB & $\mathrm{NR}\|/ \mathrm{NR}\|+\mathrm{EB}$ \\
\hline \multicolumn{7}{|l|}{ Ingredients (\%) } \\
\hline Corn & 40.73 & 43.51 & 44.09 & 45.75 & 48.53 & 49.11 \\
\hline Soybean meal (45\% CP) & 39.00 & 38.50 & 38.41 & 32.54 & 32.07 & 31.97 \\
\hline Defatted rice bran ${ }^{1}$ & 10.0 & 10.0 & 10.0 & 10.0 & 10.0 & 10.0 \\
\hline Vegetable fat & 6.33 & 4.54 & 4.06 & 7.80 & 6.01 & 5.53 \\
\hline Limestone & 1.26 & 1.30 & 1.30 & 1.29 & 1.33 & 1.33 \\
\hline Monodicalcium phosphate & 1.64 & 1.08 & 1.08 & 1.58 & 1.01 & 1.01 \\
\hline Salt & 0.46 & 0.46 & 0.46 & 0.46 & 0.46 & 0.46 \\
\hline DL-Met & 0.26 & 0.26 & 0.25 & 0.25 & 0.25 & 0.25 \\
\hline L-Lys HCl & 0.11 & 0.12 & 0.12 & 0.15 & 0.16 & 0.16 \\
\hline Monensin (200 g/kg) & 0.05 & 0.05 & 0.05 & 0.05 & 0.05 & 0.05 \\
\hline Choline chloride (600 g/kg) & 0.05 & 0.05 & 0.05 & 0.04 & 0.04 & 0.04 \\
\hline Mineral premix $x^{2,3}$ & 0.10 & 0.10 & 0.10 & 0.06 & 0.06 & 0.06 \\
\hline Vitamin premix $x^{4,5}$ & 0.05 & 0.05 & 0.05 & 0.03 & 0.03 & 0.03 \\
\hline Enzyme blend ${ }^{6}$ & $-/ 0.02$ & $-/ 0.02$ & $-/ 0.02$ & $-/ 0.02$ & $-/ 0.02$ & $-/ 0.02$ \\
\hline \multicolumn{7}{|l|}{ Chemical composition (calculated) ${ }^{7}$} \\
\hline Metabolizable energy (kcal/kg) & 3,050 & 2,975 & 2,950 & 3,150 & 3,075 & 3,050 \\
\hline Crude protein (\%) & 21.5 & 21.5 & 21.5 & 20.0 & 20.0 & 20.0 \\
\hline $\mathrm{Ca}(\%)$ & 0.95 & 0.85 & 0.85 & 0.90 & 0.80 & 0.80 \\
\hline Available P (\%) & 0.45 & 0.35 & 0.35 & 0.42 & 0.32 & 0.32 \\
\hline $\mathrm{Na}(\%)$ & 0.20 & 0.20 & 0.20 & 0.20 & 0.20 & 0.20 \\
\hline SID Arginine (\%) & 1.33 & 1.32 & 1.32 & 1.28 & 1.28 & 1.27 \\
\hline SID Lysine (\%) & 1.16 & 1.16 & 1.16 & 1.09 & 1.09 & 1.09 \\
\hline SID Methionine + Cystine (\%) & 0.86 & 0.86 & 0.86 & 0.78 & 0.78 & 0.78 \\
\hline SID Methionine (\%) & 0.54 & 0.54 & 0.54 & 0.52 & 0.52 & 0.52 \\
\hline SID Tryptophan (\%) & 0.26 & 0.25 & 0.25 & 0.22 & 0.22 & 0.22 \\
\hline SID Threonine (\%) & 0.71 & 0.71 & 0.71 & 0.66 & 0.66 & 0.66 \\
\hline
\end{tabular}

'Chemical composition: Dry matter, 89.13\%; crude protein, 15.11\%; ash, 10.64\%; gross energy, 3,634 kcal/kg.

${ }^{2}$ Supply per $\mathrm{kg}$ of starter diet: $\mathrm{Cu}, 15 \mathrm{mg}$ as copper sulfate; $\mathrm{Fe}, 80 \mathrm{mg}$ as ferrous sulfate; I, $1.2 \mathrm{mg}$ as potassium iodide; $\mathrm{Mn}, 150 \mathrm{mg}$ as manganous oxide; Se, $0.3 \mathrm{mg}$ as sodium selenite; and Zn, $100 \mathrm{mg}$ as zinc oxide.

${ }^{3}$ Supply per $\mathrm{kg}$ of grower diet: $\mathrm{Cu}, 9 \mathrm{mg}$ as copper sulfate; $\mathrm{Fe}, 48 \mathrm{mg}$ as ferrous sulfate; l, $0.72 \mathrm{mg}$ as potassium iodide; $\mathrm{Mn}, 90 \mathrm{mg}$ as manganous oxide; Se, $0.3 \mathrm{mg}$ as sodium selenite; and $\mathrm{Zn}, 60 \mathrm{mg}$ as zinc oxide.

${ }^{4}$ Supply per $\mathrm{kg}$ of starter diet: vitamin A, 116,600 IU; vitamin D, 2,800 IU; vitamin E, 26 mg; vitamin K, 3 mg; vitamin B1, 3 mg; vitamin B2, 9 mg; vitamin B6, 4.5 mg; vitamin B12, $20 \mu \mathrm{g}$; pantothenic acid, $22 \mathrm{mg}$; niacin, $66 \mathrm{mg}$; folic acid, $1.2 \mathrm{mg}$; and biotin, $100 \mu \mathrm{g}$.

${ }^{5}$ Supply per kg of grower diet: vitamin A, 696,0 IU; vitamin D, 1,680 IU; vitamin E, $15.6 \mathrm{mg}$; vitamin K, $1.8 \mathrm{mg}$; vitamin B1, 1.8 mg; vitamin B2, 5.4 mg; vitamin B6, $2.7 \mathrm{mg}$; vitamin B12, $12 \mu \mathrm{g}$; pantothenic acid, $13.2 \mathrm{mg}$; niacin, $39.6 \mathrm{mg}$; folic acid, $0.72 \mathrm{mg}$; and biotin, $60 \mu \mathrm{g}$.

${ }^{6} \mathrm{Allzyme} \mathrm{SSF} \Theta$, composed of alpha-amylase, beta-glucanase, cellulase, pectinase, phytase, fungal protease, and xylanase; derived from Aspergillus niger.

${ }^{7}$ Rostagno et al. (2005).

${ }^{8}$ SID = standardized ileal digestible values (Rostagno et al., 2005)

ST = standard diet; NR I = diet with nutrient reduction (less $75 \mathrm{kcal} \mathrm{ME} / \mathrm{kg}, 0.1 \%$ of $\mathrm{Ca}$, and $0.1 \%$ of available P than in the standard diet); NR II = diet with nutrient reduction (less $100 \mathrm{kcal} \mathrm{ME} / \mathrm{kg}, 0.1 \%$ of $\mathrm{Ca}$, and $0.1 \%$ of available P than the standard diet); $\mathrm{EB}=$ enzyme blend.

\section{RESULTS AND DISCUSSION}

No interaction between diet and EB was observed for any of the performance responses (Table 2). The addition of $200 \mathrm{~g} \mathrm{EB/t}$ of feed did not affect broiler performance parameters. Cotta et al. (2002), adding three levels $(0.5,1.0$ and $1.5 \mathrm{~g} / \mathrm{kg}$ diet) of an EB composed of $\alpha$-amylase, protease and xylanase, and Strada (2004), using an EB with these same components, did not detect any differences in broiler performance either. On the other hand, Cardoso et al. (2010) observed worse performance in broilers fed an exogenous amylase associated with an EB consisting of xylanase, $\beta$-glucanase, galactomannanase, and 
Table 2 - Effects of dietary enzyme blend (EB) supplementation and nutrient reduction (NR) on the performance of broiler chickens $^{1}$

\begin{tabular}{|c|c|c|c|c|c|c|c|c|c|c|}
\hline \multirow[b]{2}{*}{ Item } & \multicolumn{3}{|c|}{ Enzyme blend } & \multicolumn{4}{|c|}{ Nutrient Reduction } & \multicolumn{3}{|c|}{$p$-value } \\
\hline & - & + & $\mathrm{SEM}^{2}$ & Standard & $1^{3}$ & $\|^{4}$ & SEM & EB & NR & $E B \times N R$ \\
\hline \multicolumn{11}{|l|}{ BW, $g^{5}$} \\
\hline d 21 & 994 & 1,011 & 8.8 & $1,027^{a}$ & $977^{b}$ & $1,004^{\mathrm{ab}}$ & 10.8 & 0.18 & 0.01 & 0.70 \\
\hline d 38 & 2,474 & 2,502 & 30.6 & 2,476 & 2,492 & 2,497 & 37.4 & 0.52 & 0.92 & 0.28 \\
\hline \multicolumn{11}{|l|}{ Feed intake, g } \\
\hline Starter period & 1,221 & 1,234 & 10.2 & 1,224 & 1,232 & 1,228 & 12.4 & 0.38 & 0.90 & 0.98 \\
\hline Grower period & 2,617 & 2,599 & 38.5 & 2,547 & 2,601 & 2,677 & 47.2 & 0.75 & 0.16 & 0.57 \\
\hline Overall & 3,835 & 3,828 & 40.6 & 3,770 & 3,819 & 3,905 & 49.7 & 0.90 & 0.17 & 0.58 \\
\hline \multicolumn{11}{|l|}{ BWG, $g^{6}$} \\
\hline Starter period & 943 & 961 & 8.8 & $976^{a}$ & $926^{b}$ & $954^{\mathrm{ab}}$ & 10.7 & 0.16 & 0.01 & 0.67 \\
\hline Grower period & 1,488 & 1,455 & 28.2 & 1,448 & 1,495 & 1,471 & 34.5 & 0.42 & 0.64 & 0.78 \\
\hline Overall & 2,409 & 2,413 & 28.9 & 2,398 & 2,409 & 2,425 & 35.4 & 0.92 & 0.85 & 0.32 \\
\hline \multicolumn{11}{|l|}{$\mathrm{G}: \mathrm{F}^{7}$} \\
\hline Starter period & 0.772 & 0.779 & 0.008 & $0.797^{a}$ & $0.752^{c}$ & $0.777^{b}$ & 0.010 & 0.34 & 0.001 & 0.62 \\
\hline Grower period & 0.569 & 0.560 & 0.021 & 0.569 & 0.575 & 0.549 & 0.026 & 0.80 & 0.09 & 0.71 \\
\hline Overall & 0.628 & 0.630 & 0.009 & $0.636^{a}$ & $0.631^{\mathrm{ab}}$ & $0.621^{b}$ & 0.011 & 0.36 & 0.05 & 0.60 \\
\hline
\end{tabular}

a,bMeans in the same row with different superscripts differ $(p \leq 0.05)$.

${ }^{1}$ There were 9 replicates/treatment. Starter period $=d 1$ to 21 , and grower period $=d 21$ to 38 .

${ }^{2}$ Pooled SEM.

${ }^{3} \mathrm{NR} \mathrm{I}=$ diet with nutrient reduction I, reduction of $75 \mathrm{kcal} \mathrm{ME} / \mathrm{kg}, 0.1 \%$ of $\mathrm{Ca}$, and $0.1 \%$ of available P.

${ }^{4} \mathrm{NR} \| \mathrm{I}=$ diet with nutrient reduction $\mathrm{I}$, reduction of $100 \mathrm{kcal} \mathrm{ME} / \mathrm{kg}, 0.1 \%$ of $\mathrm{Ca}$, and $0.1 \%$ of available $\mathrm{P}$.

${ }^{5} \mathrm{BW}=$ body weight.

${ }^{6} \mathrm{BWG}=$ body weight gain.

${ }^{7} \mathrm{G}: \mathrm{F}=$ gain/feed ratio.

$\alpha$-galactosidase between 1 and 35 d compared with a control diet. In layers, Manzke et al. (2010) added the same EB used in the present experiment applied "on top", i.e. not considering energy recovery supplied by $E B$, of diets based on corn and soybean meal, and did not observe any effect on performance parameters. The obtained results were expected because enzyme effects on performance are not usually observed when standard diets based on balanced and high digestible nutrients are fed. For example, Selle et al. (1999) fed a standard or a modified sorghum-based diet containing or not 600 FTU phytase/kg to 7- to 21-d-old broilers. The modified diets contained reduced specifications of $\mathrm{P}, \mathrm{Ca}$, protein, and energy. Phytase did not influence the performance of broilers fed the standard diets, but ADG (7.6\%) and G:F (4.7\%) increased when the modified diets were supplied.

As expected, the broilers fed the standard diet presented better performance than those fed the NR diets. During the starter period, birds fed the standard diet showed higher BW gain and BW compared with the NR I group. The NR I diet resulted in the worst
$G: F$, while NR II was intermediate $(p>0.05)$. This result has no obvious biological explanation and the NR diets presented similar analyzed GE (NR I: 4,094 kcal/kg and NR II: 4,103 kcal/ $\mathrm{kg}$ ). The birds fed the NR diets were not able to adjust their feed intake $(p>0.05)$ to compensate the reduced supply of energy.

According to Leeson et al. (1996), broilers fed marginal NR diets tend to increase their feed intake as dietary energy is reduced. Despite the lack of statistical difference, the birds fed the RN diets showed a numerical increase in feed intake $(p>0.05)$. During the entire experimental period, broilers fed the standard diet presented better $G: F(p \leq 0.05)$ than those on NR II, whereas the G:F results of those supplied with the NR I diet were intermediate. Raber et al. (2009) also observed better G:F in broilers fed the higher energy diet compared with a standard diet.

There was no interaction of the evaluated factors on metabolic parameters (Table 3). As previously observed with performance results, no metabolic differences were detected between broilers fed diets with or without $E B$, frustrating the expectation that the enzyme blend 
Table 3 - Effects of an enzyme blend (EB) supplementation and nutrient reduction (NR) on the coefficients of total tract apparent retention (CTTAR) of dry matter (DM), crude protein (CP), gross energy (GE), and apparent metabolizable energy (AME) content of diets fed broilers from d 14 to 17 and d 28 to $31^{1}$

\begin{tabular}{|c|c|c|c|c|c|c|c|c|c|c|}
\hline \multirow[b]{2}{*}{ Item } & \multicolumn{3}{|c|}{ Enzyme blend } & \multicolumn{4}{|c|}{ Nutrient Reduction } & \multicolumn{3}{|c|}{ p-value } \\
\hline & - & + & $\mathrm{SEM}^{2}$ & Standard & $1^{3}$ & $\|^{4}$ & SEM & EB & NR & $E B \times N R$ \\
\hline \multicolumn{11}{|l|}{14 to $17 d$} \\
\hline CTTAR of DM & 0.674 & 0.674 & 0.360 & $0.683^{a}$ & $0.661^{b}$ & $0.677^{a}$ & 0.441 & 0.88 & 0.003 & 0.45 \\
\hline CTTAR of CP & 0.653 & 0.661 & 0.473 & $0.673^{\mathrm{a}}$ & $0.674^{a}$ & $0.624^{b}$ & 0.580 & 0.24 & 0.001 & 0.10 \\
\hline CTTAR of GE & 0.737 & 0.739 & 0.293 & $0.749^{a}$ & $0.725^{b}$ & $0.740^{\mathrm{a}}$ & 0.359 & 0.71 & 0.001 & 0.26 \\
\hline AME, kcal/kg & 3035 & 3055 & 12.11 & $3129^{a}$ & $2978^{c}$ & $3028^{b}$ & 14.83 & 0.26 & 0.001 & 0.07 \\
\hline \multicolumn{11}{|l|}{28 to $31 \mathrm{~d}$} \\
\hline CTTAR of DM & 0.698 & 0.692 & 0.415 & $0.696^{a b}$ & $0.686^{b}$ & $0.703^{\mathrm{a}}$ & 0.508 & 0.36 & 0.070 & 0.94 \\
\hline CTTAR of CP & 0.656 & 0.654 & 0.408 & $0.669^{a}$ & $0.665^{a}$ & $0.630^{b}$ & 0.500 & 0.73 & 0.001 & 0.21 \\
\hline CTTAR of GE & 0.762 & 0.757 & 0.357 & $0.767^{a}$ & $0.750^{\mathrm{b}}$ & $0.762^{\mathrm{ab}}$ & 0.437 & 0.30 & 0.030 & 0.99 \\
\hline AME, $\mathrm{kcal} / \mathrm{kg}$ & 3,141 & 3,127 & 14.71 & $3,193^{a}$ & $3,090^{b}$ & $3,118^{b}$ & 18.01 & 0.51 & 0.001 & 0.46 \\
\hline
\end{tabular}

a,b Means in the same row with different superscripts differ $(p \leq 0.07)$.

'There were 9 replicates/treatment.

${ }^{2}$ Pooled SEM.

${ }^{3} \mathrm{NR} \mathrm{I}=$ diet with nutrient reduction I, reduction of $75 \mathrm{kcal} \mathrm{ME} / \mathrm{kg}, 0.1 \%$ of $\mathrm{Ca}$, and $0.1 \%$ of available $\mathrm{P}$.

${ }^{4} \mathrm{NR} \| \mathrm{I}=$ diet with nutrient reduction $\mathrm{I}$, reduction of $100 \mathrm{kcal} \mathrm{ME} / \mathrm{kg}, 0.1 \%$ of $\mathrm{Ca}$, and $0.1 \%$ of available $\mathrm{P}$.

would compensate the energy reductions applied to the nutritional matrix of the NR diets.

An improvement in the energy value of the diet was expected because it is well known that in diets with cereal grains containing high NSP levels, such as DRB, carbohydrase supplementation improves energy utilization (Adeola \& Cowieson, 2011). This effect is achieved first by a reduction in digesta-viscosity, breaking the feedstuffs' physical barriers to allow the action of digestive enzymes, such as amylases and proteases, on their substrates (Choct, 2006). However, dietary ME has to be considered because the effect of carbohydrase may be masked when dietary ME levels are high. Zhou et al. (2009) showed when the dietary ME level increased from 2,780 to 3,085 MJ/kg, the effect of carbohydrases was reduced. In the present experiment, AME increased from 2,978 kcal/ $/ \mathrm{kg}$ in the $\mathrm{NR}$ diets to $3,193 \mathrm{kcal} / \mathrm{kg}$ in the standard diet, which values are higher than those reported in the study of Zhou et al. (2009) may provide an explanation for the lack of effect of the enzyme blend herein.

On the other hand, all metabolism responses were significantly influenced $(p<0.05)$ by the standard diet, NR I, and NR II. During both periods, only the CTTAR of CP of the NR I diet was similar to that obtained with the standard diet. The NR I diet resulted in the worst responses of all other evaluated parameters during both periods. The NR II diet promoted similar CTTAR of DM and GE to the standard diet and contained intermediate AME during the starter period. During both periods, NR II resulted in the lowest CTTAR of CP.

Contradictory results concerning the action of enzymes on metabolic responses were also observed by other researchers. Rizzoli (2009) and Pucci et al. (2003) did not find any beneficial effect of exogenous enzymes on CTTAR of DM or AME. On the other hand, Giacometti et al. (2002) observed an increase in dietary AME with the dietary addition of an EB composed of protease, xylanase, and phytase, compared with diets containing glucanase and xylanase or only xylanase (250 $\mathrm{g} / \mathrm{t})$, suggesting the possibility that a larger number of enzymes may improve nutrient digestibility. However, when 30\% DRB was included in the diets, the best AME response was obtained with the diet containing only xylanase, justified by the greater presence of arabinoxylans in the feedstuffs. This positive effect of xylanase was also observed by Schoulten et al. (2003), who evaluated diets with two DRB levels (10 or $20 \%$ ) and four xylanase levels $(0,200,400$, or $600 \mathrm{~g} / \mathrm{t})$ and concluded that higher DRB dietary inclusion required higher xylanase suplementation.

The lack of effect of EB on metabolism results may be related with the inefficiency of EB products in making nutrients available, perhaps as a consequence of the substrate and the microorganism chosen for the process of solid-state fermentation to produce the enzymes. The EB used in the current study was produced by fungi of the genus Aspergillus using wheat bran as substrate. Silveira \& Furlong (2007) 
used an EB produced using DRB as substrate and two different microorganisms (Rhizopus sp. and Aspergillus oryzae) to analyze their ability to supply nutrients and obtained better responses when the EB was produced by the fungi of the genus Rhizopus.

Interestingly, the results in Table 4 show better nutrient utilization $(p<0.05)$ during the grower period compared with the starter period. The higher CTTAR of DM and GE can be interpreted as a consequence of the digestive system maturation of the broilers and their adaptation to the DRB. According Macari et al. (1994), the absorption of fat by young birds is limited and the structure of the enterocytes is fully developed and the mechanisms of lipid digestion and absorption are effective only 2 to 3 weeks after hatch. Using various sources of fat, Whitehead \& Fisher (1975) and Sell et al. (1986) also observed an increase in the digestibility of fat as birds aged. These results can be also associated with higher pancreatic lipase activity. Sakomura et al. (2004) tested broiler lipase activity weekly and observed a quadratic effect: the activity increased up until the $3^{\text {rd }}$ week and remained constant until the $6^{\text {th }}$ week of life. In that same study, the authors observed that trypsin activity linearly increased with age and the period of greatest development is between the first and the second week of life. In the present study, only CTTAR of CP showed no differences between the collection periods.

Table 4 - Comparison of the coefficients of total tract apparent retention (CTTAR) of dry matter (DM), crude protein $(C P)$, and gross energy (GE) content of broiler diets during two periods: $d 14$ to 17 and d 28 to 31

\begin{tabular}{lcccc}
\hline & \multicolumn{4}{c}{ Period } \\
\hline Item & $14-17 \mathrm{~d}$ & $28-31 \mathrm{~d}$ & SEM & p-value \\
\hline CTTAR of DM, \% & $67.4^{\mathrm{b}}$ & $69.5^{\mathrm{a}}$ & 0.3 & 0.001 \\
\hline CTTAR of GE, \% & $73.8^{\mathrm{b}}$ & $76.0^{\mathrm{a}}$ & 0.2 & 0.001 \\
\hline CTTAR of CP, \% & 65.7 & 65.3 & 0.4 & 0.52 \\
\hline
\end{tabular}

$a, b$ Means in the same row with different superscripts differ $(p \leq 0.05)$.
There was no interaction between the evaluated factors for $\mathrm{P}$ retention (Table 5). In the starter period, birds receiving the standard diet retained more $P$ ( $p$ $<0.001)$ than those fed the NR diets, whereas in the grower period this difference was not significant. As expected, the phytase present in the EB hydrolyzed the phytic phosphorus increasing its absorption (Nelson et al., 1971; Simons et al., 1990) as shown by the increase in $6.58 \%(p \leq 0.07)$ and $8.55 \%$ of $P$ retention ( $p<0.05$ ) during the starter and grower periods, respectively. Phosphorus excretion is reduced when phytase is added to poultry diets (Kornegay et al., 1997). The results of the present study are consistent with the findings of Pessoa et al. (2010), who fed broiler chickens from 20 to $25 \mathrm{~d}$ old with the same EB at the same dose and observed a $10.26 \%$ increase in the $P$ retention. The reduced $P$ excretion by broilers fed diets with enzyme supplementation is also beneficial for the environment, preventing water contamination (Selle et al., 2007).

Bone mineralization results (tibiotarsus ash as a percentage of DM) were not different on d 21, but on $\mathrm{d} 38$, tibiotarsus ash content was approximately $2.45 \%$ higher in the group fed the EB than in the control group ( $p \leq 0.06$, Table 6 ). This result is consistent with $\mathrm{P}$ retention data. Conte et al. (2003), feeding broilers with diets containing phytase and xylanase, 15\% RB, and reduced levels of $P$, observed a linear increase in tibiotarsus ash as phytase supplementation levels increased. Ribeiro et al. (2003) also observed higher tibiotarsus ash content and breaking strength in broilers fed a diet with 10\% RB supplemented with 280 FTU of phytase/kg compared with those not fed phytase.

It is interesting to note that different levels of RB with no enzyme supplementation may result in different bone mineralization responses. According to Gallinger et al. (2004), broilers fed 10\% RB showed no difference in tibiotarsus ash percentage compared with those fed a standard diet (corn-soybean meal),

Table 5 - Effects of an enzyme blend (EB) supplementation and nutrient reduction (NR) on P retention of broiler chickens ${ }^{1}$

\begin{tabular}{|c|c|c|c|c|c|c|c|c|c|}
\hline \multirow[b]{2}{*}{ Item } & \multicolumn{3}{|c|}{ Enzyme blend } & \multicolumn{3}{|c|}{ Nutrient Reduction } & \multicolumn{3}{|c|}{$\mathrm{p}$-value } \\
\hline & - & + & $\mathrm{SEM}^{2}$ & Standard & $I+\|\|^{3}$ & SEM & EB & NR & $E B \times N R$ \\
\hline \multicolumn{10}{|l|}{$P$ retention, $\mathrm{g}$} \\
\hline 14 to $17 \mathrm{~d}$ & $0.71^{\mathrm{b}}$ & $0.76^{\mathrm{a}}$ & 0.02 & $0.79^{a}$ & $0.69^{b}$ & 0.02 & 0.07 & 0.001 & 0.40 \\
\hline 28 to $31 \mathrm{~d}$ & $1.07^{b}$ & $1.17^{a}$ & 0.04 & 1.16 & 1.08 & 0.04 & 0.04 & 0.1 & 0.90 \\
\hline
\end{tabular}

a,b Means in the same row with different superscripts differ $(p \leq 0.07)$.

There were 9 replicates/treatment.

2Pooled SEM.

${ }^{3}$ Both diets with nutrient reduction were analyzed together as $\mathrm{Ca}$ and $\mathrm{P}$ were reduced at the same levels (reduction of $0.1 \%$ of $\mathrm{Ca}$ and $0.1 \%$ of available $\mathrm{P}$ ). 
Table 6 - Effects of an enzyme blend (EB) supplementation and nutrient reduction (NR) on bone mineralization of the tibiotarsus of broiler chickens ${ }^{1}$

\begin{tabular}{|c|c|c|c|c|c|c|c|c|c|}
\hline \multirow[b]{2}{*}{ Item } & \multicolumn{3}{|c|}{ Enzyme blend } & \multicolumn{3}{|c|}{ Nutrient Reduction } & \multicolumn{3}{|c|}{$p$-value } \\
\hline & - & + & $\mathrm{SEM}^{2}$ & Standard & $1+\|^{3}$ & SEM & $E B$ & NR & $E B \times N R$ \\
\hline \multicolumn{10}{|c|}{ Bone mineralization, \% } \\
\hline$d 21$ & 37.8 & 37.7 & 0.23 & 37.9 & 37.7 & 0.23 & 0.79 & 0.52 & 0.98 \\
\hline d 38 & $35.8^{b}$ & $36.7^{\mathrm{a}}$ & 0.35 & 36.1 & 36.3 & 0.34 & 0.06 & 0.76 & 0.69 \\
\hline
\end{tabular}

a,bMeans in the same row with different superscripts differ $(p \leq 0.06)$.

${ }^{1}$ There were 9 replicates/treatment. Bone mineralization in the tibiotarsus is expressed as \% of ash in the DM.

${ }^{2}$ Pooled SEM.

${ }^{3}$ Both diets with nutrient reduction were analyzed together as $\mathrm{Ca}$ and $\mathrm{P}$ were reduced at the same levels (reduction of $0.1 \%$ of $\mathrm{Ca}$ and $0.1 \%$ of available $\mathrm{P}$ ).

whereas higher RB inclusion levels negatively affected this response. It must be mentioned that the strong pressure for increased performance during genetic selection of broilers has increased leg dysfunction and, in some situations, their bone structure is unable to support their increasingly heavier weight.

\section{CONCLUSIONS}

Under the experimental conditions of the present study, the inclusion of an enzyme blend composed of phytase, protease, xylanase, beta-glucanase, cellulase, pectinase, fungal protease, and amylase in diets containing $10 \%$ DFB did not show any positive effects on the performance or metabolism responses of broiler chickens fed standard or NR diets. However, the enzyme blend improved $P$ retention and bone mineralization.

\section{REFERENCES}

AOAC - Association of Official Analytical Chemistry. Official methods of analysis. 16th ed. Arlington: AOAC International; 1995. 1025p.

Adeola O, Cowieson AJ. Board-invited review: Opportunities and challenges in using exogenous enzymes to improve nonruminant animal production. Journal of Animal Science 2011;89:3189-3218.

Cardoso DM, Maciel MP, Passos DP, Botelho LFR, Souza LFM, Silva DB. 2010. Desempenho de frangos de corte alimentados com dietas contendo complexo enzimático. Proceedings of the $47^{\mathrm{a}}$ Reunião Anual da Sociedade Brasileira de Zootecnia; 2010; Salvador, Bahia. Brazil.

Chae, BJ, Lee KH, Lee SK. Effects of feeding rancid rice bran on growth performance and chicken meat quality in broiler chicks. AsianAustralian Journal of Animal Science 2002;15(2):266-273

Choct M. Enzymes for the feed industry: past, present and future. World Poultry Science Journal 2006;62:5-15.

Conte AJ, Teixeira AS, Figueiredo AV, Vitti DMSS, Silva Filho JC. Efeito da fitase na biodisponibilidade do fósforo do farelo de arroz em frangos de corte. Pesquisa Agropecuária Brasileira 2002;37:547-552.

Conte AJ, Teixeira AS, Fialho ET, Schoulten NA, Bertechini AG. Efeito da fitase e xilanase sobre o desempenho e as características ósseas de frangos de corte alimentados com dietas contendo farelo de arroz. Revista Brasileira de Zootecnia 2003;32:1147-1156.

Cotta T, Torres DM, Oliveira AIG. Efeitos da adição de um complexo enzimático sobre o desempenho de frangos de corte. Ciência e Agrotecnologia 2002;26:852-857.

Domene SMA. Estudo do valor nutritivo mineral do farelo de arroz. Utilização do zinco, ferro, cobre e cálcio pelo rato em crescimento [PhD dissertation]. Campinas (SP): Universidade Estadual de Campinas; 1996.

Gallinger $\mathrm{Cl}$, Suarez DM, Irazusta A. Effects of rice bran inclusion on performance and bone mineralization in broiler chicks. Jounal of Applied Poultry Research 2004;13:183-190.

Giacometti RA. Valores energéticos e digestibilidade de nutrientes do farelo de arroz integral suplementado com complexos enzimáticos para frangos de corte [PhD dissertation]. Lavras (MG): Universidade Federal de Lavras; 2002

Krishna JG, Chandrasekaran M. Biochemical and nutritional aspects of food processing by-products. In: Chandrasekaran M, editor. Valorization of food processing by-products. Boca Raton: CRC Press; 2012. p. 167186.

Kornegay ET, Denbow EM, Zhang Z. Phytase supplementation of cornsoybean meal diets from three to seven week of age [abstr]. Poultry Science 1997;76(1):6.

Leeson S, Caston L, Summers JD. Broiler response to diet energy. Poultry Science 1996;75:529-535.

Macari M, Furlan R, Gonzales E. Fisiologia aviária aplicada à frangos de corte. Jaboticabal: FUNEP-UNESP; 1994.

Manzke NE, Gentilini FP, Goncalves FM, Provenci M, Anciuti MA, Rutz F. Complexo enzimático em dietas de poedeiras contendo milho e sorgo baixo tanino sobre o desempenho e qualidade dos ovos. Proceedings of the $47^{a}$ Reunião Anual da Sociedade Brasileira de Zootecnia; 2010; Salvador, Bahia. Brasil.

Nelson TS, Shieh TR, Wodzinski RJ, Ware JH. Effect of supplemental phytase on the utilization of phytate phosphorus by chicks. Jounal of Nutrition 1971;101:1289-1293.

Oliveira MC, Gravena RA, Marques RH, Guandolini GC, Moraes VMB. Utilização de nutrientes em frangos alimentados com dietas suplementadas com fitase e níveis reduzidos de fósforo não-fítico. Arquivos Brasileiros de Medicina Veterinária 2008;60:436-441.

Pessoa GBS, Albino LFT, Araujo WAG, Ribeiro Jr. V, Rostagno HS, Maia RC. Efeito do complexo enzimático Allzyme SSF nos valores de energia metabolizável e no balanço de fósforo em dietas de frangos de corte. 
Proceedings of the $47^{a}$ Reunião Anual da Sociedade Brasileira de Zootecnia; 2010; Salvador, Bahia. Brasil.

Prates ER. Técnicas de pesquisa em nutrição animal. Porto Alegre (RS): Universidade Federal do Rio Grande do Sul; 2007.

Pucci LEA, Rodrigues PB, Freitas RTF, Bertechini AG, Carvalho EM. Níveis de óleo e adição de complexo enzimático na ração de frangos de corte. Revista Brasileira de Zootecnia 2003;32:909-917.

Raber MR, Ribeiro AML, Kessler AM, Arnaiz V. Suplementação de glicerol ou de lecitina em diferentes níveis de ácidos graxos em dietas para frangos de corte. Ciência Animal Brasileira 2009;10:745-753.

Ribeiro AML, Mireles AJ, Klasing KC. Interactions between dietary phosphorus level, phytase supplementation and pelleting on performance and bone parameters of broilers fed high levels of rice bran. Animal Feed Science and Technology 2003;103:155-161.

Ribeiro AM, Penz Jr. AM, Belay TK, Teeter R. Comparison of different drying techniques for nitrogen analysis of poultry excreta, feces, and tissue. Journal of Applied Poultry Research 2001;10:21-23.

Rizzoli PW. Desempenho, incremento de energia e digestibilidade de nutrientes em rações de frangos de corte contendo enzimas exógenas [PhD dissetation]. Pirassununga (SP): Universidade de São Paulo; 2009.

Rostagno HS, Albino LFT, Donzele JL. Tabelas brasileiras para aves e suínos: composição de alimentos e exigências nutricionais. 2nd ed. Viçosa: Universidade Federal de Viçosa; 2007.

Sakomura NK, Bianchi, M, Pizauro Jr. JM, Café MB, Freitas ER. Efeito da idade dos frangos de corte sobre a atividade enzimática e digestibilidade dos nutrientes do farelo de soja e da soja integral. Revista Brasileira de Zootecnia 2004;33(4):924-935.

SAS Institute. SAS ${ }^{\oplus}$ user's guide: statistics. 9.1 version. Cary, NC; 2002.

Schoulten NA, Teixeira AS, Rodrigues PB, Freitas RTF, Conte AJ, Silva HO. Desempenho de frangos de corte alimentados com ração contendo farelo de arroz e enzimas. Ciência e Agrotecnologia 2003;27:13801387.

Sell JL, Krogdhal A, Hanyu N. Influence of age on utilization of supplemental fats by young turkeys. Poultry Science 1986;65:546-554.
Selle PH, Ravindran V, Pittolo PH, Bryden WL. An evaluation of microbial phytase in sorghum-based broiler diets. Proceedings of the Australian Poultry Science Symposium; 1999; Sidney. Australia: University of Sidney; 1999. p. 97-100.

Selle PH, Ravindran V. Microbial phytase in poultry nutrition. Animal Feed Science and Technology 2007;135:1-41.

Silveira CM, Furlong EB. Caracterização de compostos nitrogenados presentes em farelos fermentados em estado sólido. Ciência e Tecnologia de Alimentos 2007;27:805-811.

Simons PCM, Versteegh HAJ, Jongbloed AW, Kemme PA, Slump P, Bos KD, Wolters MGE, Beudeker RF, Verschoor GJ. Improvement in phosphorus availability by microbial phytase in broilers and swine. British Journal of Nutrition 1990;64:525-540.

Soto-Salanova M. The use of enzyme to improve the nutritional value of corn-soy diets for poultry and swine. Proceeding of the Simpósio Latino-Americano de Nutrição de Suínos e Aves; 1996; Campinas, São Paulo. Brazil.

Strada ESO. Uso de enzimas na alimentação de frangos de corte [phD dissertation]. Cruz das Almas (BA): Universidade Federal da Bahia; 2004.

Tedesco MJ, Gianello C, Bissani CA, Bohnen H, Volkweiss SJ. Análises de solos, plantas e outros materiais. 2nd ed. Porto Alegre: Universidade Federal do Rio Grande do Sul; 1995.

Van Hoed V, Depaemelaere G, Vila Ayal J, Santiwattana P, Verhé R, W DG. Influence of chemical refining on the major and minor components of rice bran oil. Journal of the American Oil Chemist's Society 2006;83:315-321.

Whitehead GC, Fisher $C$. The utilization of various fats by turkey of different ages. British Poultry Science 1975;16:481-485.

Yan F, Keen CA, Zhang KY, Waldroup PW. Comparison of methods to evaluate bone mineralization. Journal of Applied Poultry Research 2005;14:492-498

Zhou Y, Jiang Z, Lv D, Wang T. Improved energy utilizing efficiency by enzyme preparation supplement in broiler diets with different metabolizable energy levels. Poultry Science 2009;88:316-322. 